\title{
Carboxyl-Rich Carbon Dots as Highly Selective and Sensitive Fluorescent Sensor for Detection of $\mathrm{Fe}^{3+}$ in Water and Lactoferrin
}

\author{
Xinxin Wang ${ }^{1}$, Yanan Zhao ${ }^{1}$, Ting Wang ${ }^{2}$, Yan Liang ${ }^{1, *}$, Xiangzhong Zhao ${ }^{1}$, Ke Tang ${ }^{2}$, Yutong Guan ${ }^{1}$ \\ and Hua Wang ${ }^{3, *}$ \\ 1 College of Food Science and Engineering, Qilu University of Technology (Shandong Academy of Sciences), \\ Jinan 250353, China; 201695011018@stu.qlu.edu.cn (X.W.); 10431211055@stu.qlu.edu.cn (Y.Z.); \\ 1350641616@163.com (X.Z.); qlut_guanyutong@163.com (Y.G.) \\ 2 College of Biotechnology, Qilu University of Technology (Shandong Academy of Sciences), Jinan 250353, \\ China; tingwang_97@hotmail.com (T.W.); tangk2001@163.com (K.T.) \\ 3 School of Materials Science and Engineering, Shandong University, Jinan 250061, China \\ * Correspondence: liangyan@qlu.edu.cn (Y.L.); hwang@sdu.edu.cn (H.W.)
}

check for updates

Citation: Wang, X.; Zhao, Y.; Wang, T.; Liang, Y.; Zhao, X.; Tang, K.; Guan, Y.; Wang, H. Carboxyl-Rich Carbon Dots as Highly Selective and Sensitive Fluorescent Sensor for Detection of $\mathrm{Fe}^{3+}$ in Water and Lactoferrin. Polymers 2021, 13, 4317. https://doi.org/10.3390/ polym13244317

Academic Editor:

Arunas Ramanavicius

Received: 19 November 2021

Accepted: 7 December 2021

Published: 9 December 2021

Publisher's Note: MDPI stays neutral with regard to jurisdictional claims in published maps and institutional affiliations.

Copyright: (c) 2021 by the authors. Licensee MDPI, Basel, Switzerland. This article is an open access article distributed under the terms and conditions of the Creative Commons Attribution (CC BY) license (https:// creativecommons.org/licenses/by/ $4.0 /)$.

\begin{abstract}
As lactoferrin (LF) plays an essential role in physiological processes, the detection of LF has attracted increasing attention in the field of disease diagnosis. However, most current methods require expensive equipment, laborious pretreatment, and long processing time. In this work, carboxyl-rich carbon dots (COOH-CDs) were facilely prepared through a one-step, low-cost hydrothermal process with tartaric acid as the precursor. The $\mathrm{COOH}-\mathrm{CDs}$ had abundant carboxyl on the surface and showed strong blue emission. Moreover, $\mathrm{COOH}-\mathrm{CD}$ s were used as a fluorescent sensor toward $\mathrm{Fe}^{3+}$ and showed high selectivity for $\mathrm{Fe}^{3+}$ with the limit of detection (LoD) of $3.18 \mathrm{nM}$. Density functional theory (DFT) calculations were performed to reveal the mechanism of excellent performance for $\mathrm{Fe}^{3+}$ detection. Meanwhile, $\mathrm{COOH}-\mathrm{CD}$ s showed no obvious effect on lactobacillus plantarum growth, which means that $\mathrm{COOH}-\mathrm{CDs}$ have good biocompatibility. Due to the nontoxicity and excellent detection performance for $\mathrm{Fe}^{3+}, \mathrm{COOH}-\mathrm{CD}$ were employed as a fluorescent sensor toward $\mathrm{LF}$ and showed satisfying performance with an $\mathrm{LoD}$ of $0.776 \mu \mathrm{g} / \mathrm{mL}$, which was better than those of the other methods.
\end{abstract}

Keywords: carbon dots; DFT calculations; $\mathrm{Fe}^{3+}$; lactoferrin; fluorescent sensor

\section{Introduction}

Lactoferrin (LF), one number of transferrin families, is a $78 \mathrm{kDa}$ iron-binding glycoprotein that was primarily identified from bovine milk in 1939 [1]. It has been regarded as the first defensive barrier for human beings due to its significant antimicrobial property, immune modulation, and tumor growth inhibition [2]. Therefore, LF is widely used in food and medical fields, such as infant formula, dairy products, and health products [3]. Recently, the requirement of LF sharply increased, as many reports reported that LF could help to some extent in COVID-19 prevention [4-6]. However, the structure of LF can be easily destroyed and lose function during processing [7]. Therefore, LF detection is highly desirable to ensure the quality of products before products enter the market.

Various methods have been developed to detect LF, including high-performance liquid chromatography (HPLC), high-performance liquid chromatography-tandem mass spectrometry (HPLC-MS), electrochemiluminescence (ECL), and enzyme-linked immunosorbent assay (ELLSA) [8,9]. The benefits of these methods include their high sensitivity, easy operation, and wide detection range. However, they usually require expensive equipment, laborious pretreatment, and long processing time [10]. Up to date, developing an accurate, rapid, and convenient method to detect LF still remains a challenge. 
LF presents a unique structure in space with a polypeptide chain folded into two globular lobes to provide a binding site for $\mathrm{Fe}^{3+}$, and the binding reaction between LF and $\mathrm{Fe}^{3+}$ is reversible [11-13]. Kanwar et al., reported that the $\mathrm{Fe}^{3+}$ content in LF directly affected anti-tumor activity as well as apoptosis and cytotoxicity [14]. Meanwhile, Choi's group found that $\mathrm{Fe}^{3+}$ binding in LF had a pivotal influence on LF physiological function, which can control the survival and death of the cell [15]. These reports indicated that the $\mathrm{Fe}^{3+}$ embedded into LF determined the functional property of LF, and the detection of $\mathrm{Fe}^{3+}$ in LF could be used to analyze the biological activity of LF [16].

Fluorescent sensors based on carbon dots (CDs) have attracted much attention due to their good biocompatibility, low toxicity, low cost, and excellent detection performance [17]. Guo et al., developed a simple method for the preparation of N, P-doped carbon dots with highly selectivity and sensitivity toward $\mathrm{Fe}^{3+}$ to utilize in photocatalytic degradation application [18]. Li et al., prepared CDs with high detection efficiency for $\mathrm{Fe}^{3+}$ to be applied in bioimaging [19]. In our previous work, a novel $\mathrm{N}$-doped carbon dots for $\mathrm{Fe}^{3+}$ detection was demonstrated and utilized as an "on-off-on" fluorescent sensor for Streptococcus thermophilus stain-screening [20]. However, few works related to LF detection with a fluorescent sensor have been reported up to now. In this work, we demonstrated the synthesis of carboxylic carbon cots (COOH-CDs) via the hydrothermal method with tartaric acid as the precursor. The structure, morphology, and optical properties of $\mathrm{COOH}-$ $\mathrm{CDs}$ were further analyzed. Moreover, $\mathrm{COOH}-\mathrm{CDs}$ were used as a fluorescent sensor toward $\mathrm{Fe}^{3+}$ and exhibited high sensitivity and selectivity. Density functional theory (DFT) calculations were performed to study the excellent performance for $\mathrm{Fe}^{3+}$ detection. To evaluate the biocompatibility of $\mathrm{COOH}-\mathrm{CDs}$, a toxicity experiment was also carried out. Furthermore, $\mathrm{COOH}-\mathrm{CD}$ s were employed as a fluorescent sensor toward LF and showed satisfied performance.

\section{Experimental}

\subsection{Materials}

Tartaric acid and inorganic salts (including $\mathrm{FeCl}_{3} \cdot 6 \mathrm{H}_{2} \mathrm{O}, \mathrm{ZnCl}_{2}, \mathrm{CoCl}_{2} \cdot 6 \mathrm{H}_{2} \mathrm{O}, \mathrm{CrCl}_{3} \cdot 6 \mathrm{H}_{2} \mathrm{O}$, $\mathrm{CuCl}_{2} \cdot 2 \mathrm{H}_{2} \mathrm{O}, \mathrm{PbCl}_{2}, \mathrm{FeCl}_{2} \cdot 4 \mathrm{H}_{2} \mathrm{O}, \mathrm{MnCl}_{2} \cdot 4 \mathrm{H}_{2} \mathrm{O}$, and $\mathrm{BaCl}_{2} \cdot 2 \mathrm{H}_{2} \mathrm{O}$ were obtained from Shanghai Aladdin Bio-Chem Technology Co., China. Lactoferrin (extract from milk) was purchased from Shanghai Macklin Biochemical Co., Ltd, China. Lactobacillus plantarum strain was obtained from the Culture Collection in our lab. MRS medium was prepared according to the published literature.

\subsection{Characterization}

A Nicolet iS 10 FTIR spectrometer (Thermo Fisher Scientific, Shanghai, China) was utilized to measure FT-IR spectra with the range from 4000 to $400 \mathrm{~cm}^{-1}$. Ultraviolet (UV) absorption spectra were collected from a Shimadzu UV-2600 spectrometer, Japan. Photoluminescence (PL) spectra were obtained from a Hitachi F-4500 fluorescence spectrophotometer (Hitachi, Tokyo, Japan). A JEOL JEM2100 electron microscope (JEOL, Tokyo, Japan) was applied to obtain High Resolution Transmission Electron Microscope (HRTEM) images. ESCALABXi+ (Thermo Fisher Scientific, Shanghai, China) was used to collect X-ray photoelectron spectra. A OLYMPUS CX41TV biological microscope (OLYMPUS, Tokyo, Japan) was used to perform optical microscopic examination.

\subsection{Synthesis of $\mathrm{COOH}-\mathrm{CDs}$}

$\mathrm{COOH}-\mathrm{CDs}$ were prepared by the hydrothermal method (Scheme 1). Tartaric acid $(0.1 \mathrm{~g})$ was dissolved in $10 \mathrm{~mL}$ of ethanol and transferred into a Teflon reactor. The reactor was placed in an oven at $180{ }^{\circ} \mathrm{C}$ for $10 \mathrm{~h}$. After cooling to room temperature, the crude solution was first filtered through a $0.22 \mu \mathrm{m}$ membrane filter to remove large particles and then dialyzed with a dialysis bag (MWCO: $500 \mathrm{Da}$ ) for $48 \mathrm{~h}$ to obtain a transparent solution. $\mathrm{COOH}-\mathrm{CD}$ s were obtained as a pale powder by freeze drying at $-50{ }^{\circ} \mathrm{C}$ for $16 \mathrm{~h}$. 




Tartaric acid

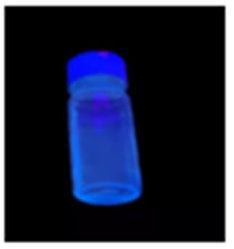

COOH-CDs

Scheme 1. The preparation process of $\mathrm{COOH}-\mathrm{CDs}$.

\subsection{Toxicity Experiment}

To evaluate the biocompatibility of $\mathrm{COOH}-\mathrm{CDs}$, a toxicity experiment was carried out [21]. Considering its application in lactoferrin detection, lactobacillus plantarum was selected as the model with viable count survival rate as the toxicity index. The reference sample was prepared using the plate smearing method by inoculating $1 \%$ lactobacillus plantarum into the MRS solid medium and culturing at $37{ }^{\circ} \mathrm{C}$ for $24 \mathrm{~h}$. Simultaneously, $0.1 \mathrm{~g} / \mathrm{mL} \mathrm{COOH}-\mathrm{CD}$ s solution was used to partly replace water $(70 \%, 80 \%$, and $90 \%)$ or glucose $(10 \%, 20 \%$, and $30 \%)$ to prepare testing samples. The toxicity of COOH-CDs was analyzed by comparing the change of viable count with the reference sample.

\subsection{Fluorescence Selectivity and Sensitive of COOH-CDs towards Fe ${ }^{3+}$ and Lactoferrin}

First, $10 \mu \mathrm{L}$ solutions $\left(10^{-3} \mathrm{~mol} / \mathrm{L}\right)$ with different kinds of metal ions were utilized to analyze the selectivity of $\mathrm{COOH}-\mathrm{CDs}(0.1 \mathrm{~g} / \mathrm{L})$ toward $\mathrm{Fe}^{3+}$. The changes of $\mathrm{COOH}-\mathrm{CDs}^{\prime}$ fluorescence intensity as $\mathrm{Fe}^{3+}$ concentration increased were measured under $317 \mathrm{~nm}$ to study the fluorescence response behavior. The fluorescence response behavior of $\mathrm{COOH}-\mathrm{CDs}$ toward Lactoferrin was investigated by the same method.

\subsection{Theoretical Calculations}

To reveal the fluorescent selectivity of COOH-CDs toward metal ions, density functional theory (DFT) calculations were utilized to study the interactions and electronic transition between $\mathrm{COOH}-\mathrm{CD}$ and different kinds of metal ions $\left(\mathrm{M}^{\mathrm{n}+}=\mathrm{Fe}^{3+}, \mathrm{Fe}^{2+}, \mathrm{Cr}^{3+}, \mathrm{Mg}^{2+}\right.$, $\mathrm{Ca}^{2+}, \mathrm{Mn}^{2+}, \mathrm{Mg}^{2+}, \mathrm{Co}^{2+}, \mathrm{Cu}^{2+}, \mathrm{Pb}^{2}$, and $\left.\mathrm{Zn}^{2+}\right)$. DFT-based Becke's three-parameter hybrid exchange functional and Lee-Yang-Parr correlation functional (B3LYP) using 6-31+G* basis set with the pseudopotentials SDD (for main-group metals) and Lanl2TZ (for transition metals) were performed to analyze the geometry optimizations of the $\mathrm{COOH}-\mathrm{CDs} / \mathrm{M}^{\mathrm{n}+}$ complexes and corresponding monomers [22]. To ensure all complexes set in minima potential energy surfaces, frequency calculations were processed at the same level of theory. GAUSSIAN (09 Revision 01, Gaussian Inc, Wallingford, CT, USA) and Gauss View (5.08, Gaussian Inc, Wallingford, CT, USA) were used to observe all the electronic structure calculations [20].

To calculate the binding energy (BE) of $\mathrm{COOH}-\mathrm{CDs} / \mathrm{M}^{\mathrm{n}+}$ complexes, a supramolecular approach was used with the assisted of a counterpoise (CP) procedure suggested by Boys and Bernardi to correct the basis set superposition error (BSSE) [23].

$$
B E=E_{\text {complex }}-\sum_{i=1}^{n} E_{i}
$$

As shown in Equation (1), $E_{\text {complex }}$ represents the total energy of the complex; $E_{i}$ is the energy of the monomer (i.e., $\mathrm{COOH}-\mathrm{CDs}$ and $\mathrm{M}^{\mathrm{n}+}$ ions). Grimme's (DFT-D3) dispersion correction was applied to quantify the role of dispersion energy in $\mathrm{COOH}-\mathrm{CDs} / \mathrm{M}^{\mathrm{n}+}$ complexes. 


\section{Results and Discussion}

\subsection{Characterizations of $\mathrm{COOH}-\mathrm{CDs}$}

The functional groups on the surface of $\mathrm{COOH}-\mathrm{CDs}$ were analyzed by FT-IR spectroscopy in Figure 1a. The peaks centered at 3415 and $3327 \mathrm{~cm}^{-1}$ corresponded to the stretching vibration of $\mathrm{OH}$ generated by $\mathrm{O}-\mathrm{H}$ and $\mathrm{CO}-\mathrm{OH}$ [24]. For the aromatic, the peaks centered at 3119 and $1450 \mathrm{~cm}^{-1}$ were corresponding to the stretching vibration of unsaturated $\mathrm{H}$ and skeletal vibration. The absorption peaks at 1747 and $1082 \mathrm{~cm}^{-1}$ were attributed to the stretching vibrations of $\mathrm{C}=\mathrm{O}$ and $\mathrm{C}-\mathrm{O}-\mathrm{C}$ [25]. These results indicated that abundant $-\mathrm{OH}$ and $-\mathrm{COOH}$ existed on the $\mathrm{COOH}-\mathrm{CD}^{\prime}$ s surface. The optical properties of $\mathrm{COOH}-\mathrm{CDs}$, including UV-vis absorption, fluorescence excitation, and emission spectra, were measured and shown In Figure $1 \mathrm{~b}$. The absorption peak of $\mathrm{COOH}-\mathrm{CDs}$ at $319 \mathrm{~nm}$ was aroused by $\mathrm{n}-\pi^{*}$ transitions of $\mathrm{C}=\mathrm{O}$ on the surface of $\mathrm{COOH}-\mathrm{CDs}$ [26]. The emission spectrum showed a peak with the maximum wavelength at $435 \mathrm{~nm}$ (fluorescence quantum yield was $3.62 \%$ ) under $317 \mathrm{~nm}$. The morphology and size distribution of the prepared $\mathrm{COOH}-\mathrm{CDs}$ were further analyzed by HRTEM and AFM, and these are displayed in Figure 1c,d, respectively. Furthermore, the uniform size distribution was also measured. According to the above results, $\mathrm{COOH}-\mathrm{CDs}$ exhibited a spherical shape with the average diameters ranging from 1.5 to $5 \mathrm{~nm}$ and the height around $3.3 \mathrm{~nm}$. The HRTEM of prepared COOH-CDs exhibited clearly crystalline lattice fringes $(0.21 \mathrm{~nm})$ aroused by the (100) in-plane lattice of graphene, indicating that the $\mathrm{COOH}-\mathrm{CDs}$ had a graphitic carbon core [27].

(a)

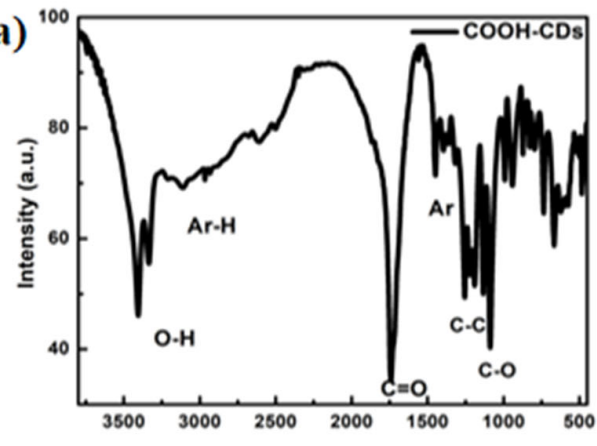

(c)

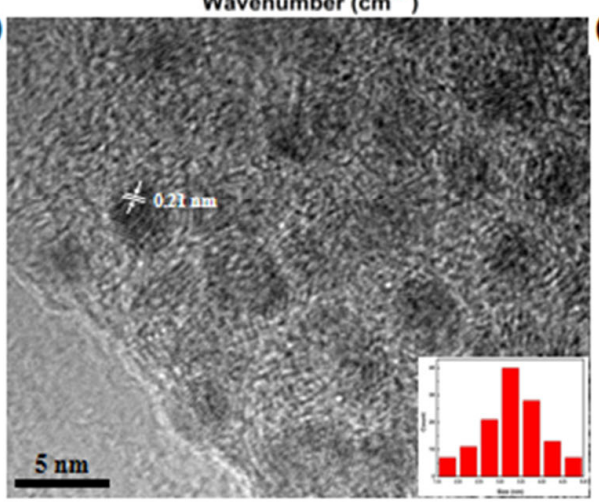

(b)

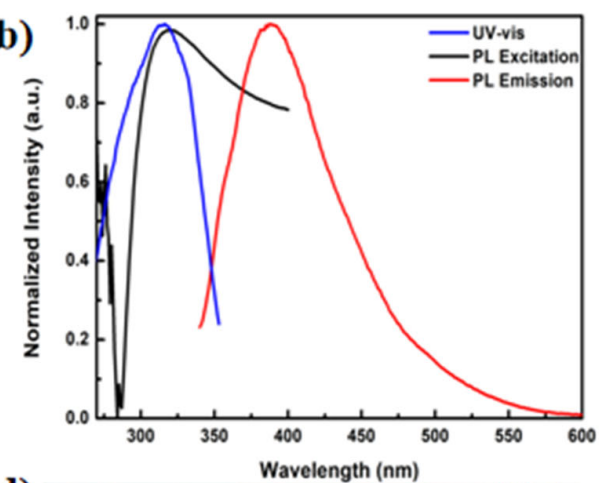

(d)

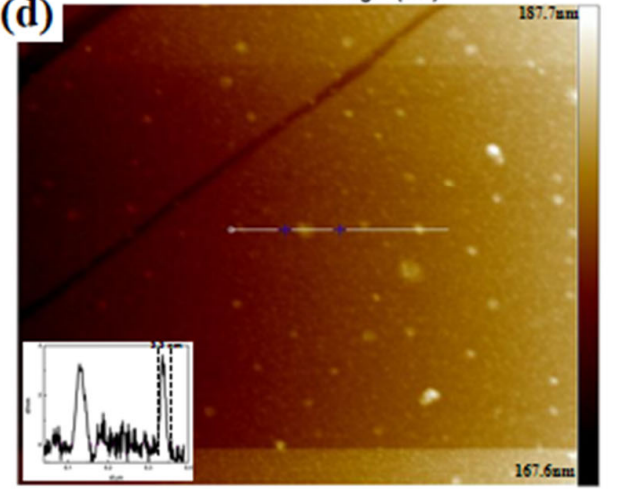

Figure 1. (a) FT-IR spectrum of $\mathrm{COOH}-\mathrm{CDs}$; (b) Absorption, fluorescence excitation, and emission spectra of COOH-CDs; (c) High-resolution TEM (HRTEM) of COOH-CDs (inner graph is particle size distribution); (d) AFM image of $\mathrm{COOH}-\mathrm{CDs}$ (inset represents height distribution of $\mathrm{COOH}-\mathrm{CDs}$ ).

X-ray photoelectron spectra were measured to further reveal the composition of $\mathrm{COOH}-\mathrm{CDs}$ (Figure 2). The three peaks of $\mathrm{C} 1 \mathrm{~s}$ at $288.8,286.4$, and $284.4 \mathrm{eV}$ corresponded to $-\mathrm{C}=\mathrm{O}, \mathrm{C}-\mathrm{O}-\mathrm{C}$, and $\mathrm{C}-\mathrm{C}$, respectively [28-30]. The three peaks in the $\mathrm{O} 1 \mathrm{~s}$ spectrum can be attributed to $\mathrm{C}-\mathrm{O}(533.08 \mathrm{eV}), \mathrm{C}-\mathrm{O}-\mathrm{C} / \mathrm{C}-\mathrm{OH}(532.37 \mathrm{eV})$, and $\mathrm{C}=\mathrm{O}(531.6 \mathrm{eV})[31,32]$. The XPS data were consistent with the FT-IR results, which further confirmed that abundant hydroxy and carboxylic groups existed on the surface of the prepared $\mathrm{COOH}-\mathrm{CDs}$. 

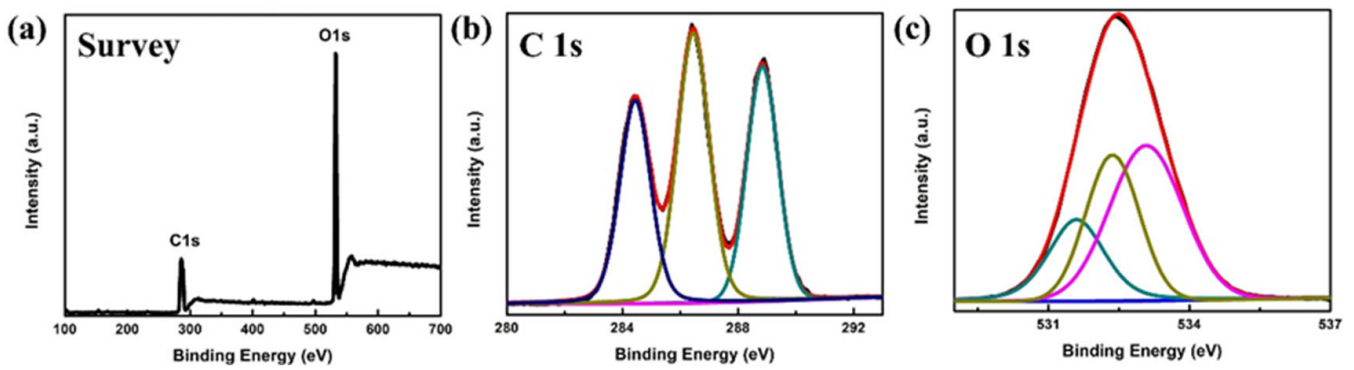

Figure 2. (a) XPS spectrum of COOH-CDs; high-resolution XPS spectra of (b) C 1s and (c) O 1s.

\subsection{Effects of Excitation Wavelength and $p H$ on Fluorescent Emission}

As shown in Figure 3a, $\mathrm{COOH}-\mathrm{CDs}$ showed a typical excitation-dependent feature. With the increasing of excitation wavelength from 280 to $380 \mathrm{~nm}$, the PL peak gradually red-shifted to a longer wavelength, indicating that the PL emission can be easily tuned by adjusting the excitation wavelength. This excitation-dependent phenomenon can be attributed to the interplay of the core and functional groups on the surface of $\mathrm{COOH}-\mathrm{CDs}$ [33]. It is well known that $\mathrm{pH}$ plays an important role in chemical environments of living things; thus, the PL emission of $\mathrm{COOH}-\mathrm{CDs}$ under different kinds of $\mathrm{pH}$ was further investigated [34]. As shown in Figure 3b, the PL emission of COOH-CDs exhibited a pH-dependent feature and strong PL emissions in all $\mathrm{pH}$ environments. The emission peak gradually red-shifted with the $\mathrm{pH}$ ranging from 1 to 11 , and the intensity firstly increased from 1 to 5 and then declined from 5 to 11 . These results can be attributed to the protonation and deprotonation process of $\mathrm{COOH}$ on the $\mathrm{CDs}$ ' surface [35]. $\mathrm{COOH}$ turned to $\mathrm{COO}^{-}$with increasing $\mathrm{pH}$ and led to the formation of a delocalized $\pi$ bond and the increase in $\mathrm{n}$ electrons, indicating that $\mathrm{COOH}-\mathrm{CDs}$ can be used in any environment with $\mathrm{pH}$ ranging from 1 to 11 .
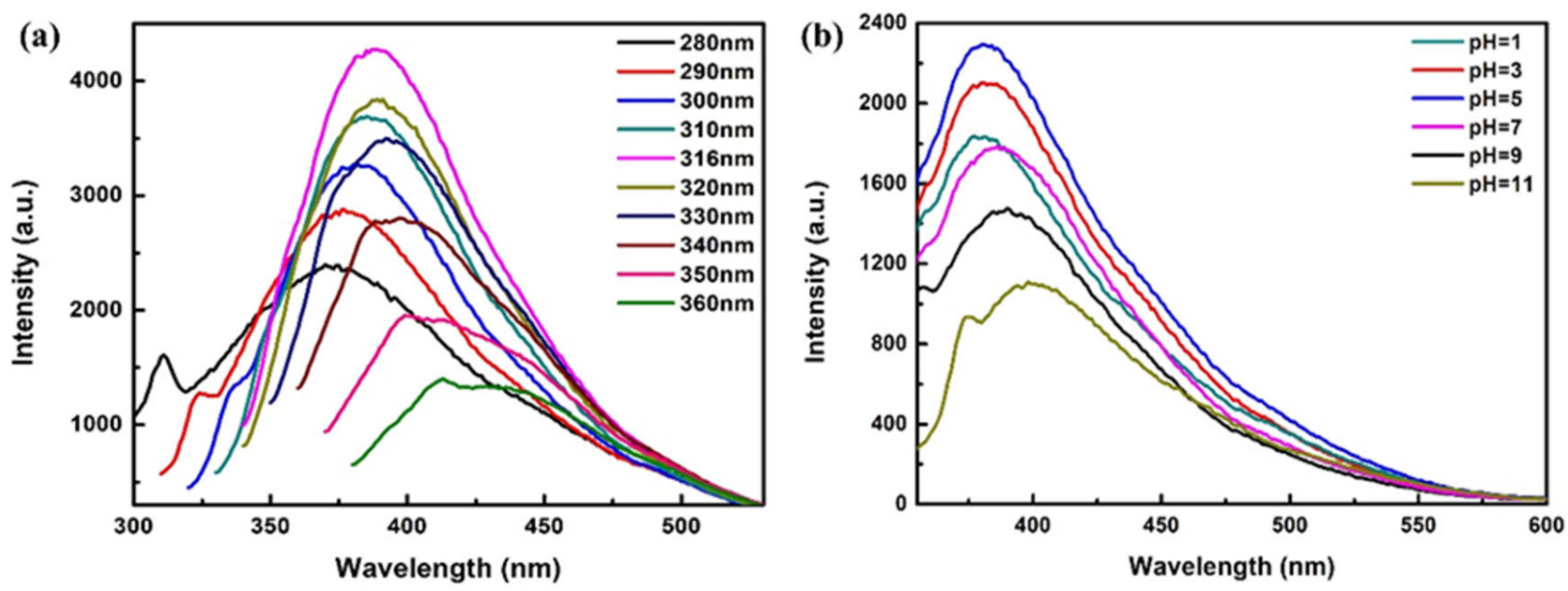

Figure 3. PL spectra of $\mathrm{COOH}-\mathrm{CDs}(\mathbf{a})$ under different excitation wavelengths and (b) under different $\mathrm{pH}$.

\subsection{Toxicity Study of COOH-CDs}

The nontoxicity property of carbon dots made it superior to other fluorescent sensors, especially in biological sample detection. $\mathrm{COOH}-\mathrm{CDs}$ solution was partly substituted with water or glucose to analyze the influence of $\mathrm{COOH}-\mathrm{CDs}$ on the growth of lactobacillus plantarum. As shown in Figure 4a,b, the addition of $\mathrm{COOH}-\mathrm{CDs}$ had no obvious effect on lactobacillus plantarum growth. Intriguingly, the survival rate showed an increasing trend with the addition of COOH-CDs. In Figure 4c, the survival rate presents a steady upward trend when $\mathrm{COOH}-\mathrm{CDs}$ partly replaced water or glucose. This result implied that $\mathrm{COOH}-\mathrm{CDs}$ is a wonderful carbon source for bacterium and has great potential 
in bacterium culture. Meanwhile, these results further confirmed that $\mathrm{COOH}-\mathrm{CD}$ are nontoxic, which means they can be developed as a fluorescent sensor for bioactive substance detect in practical application.
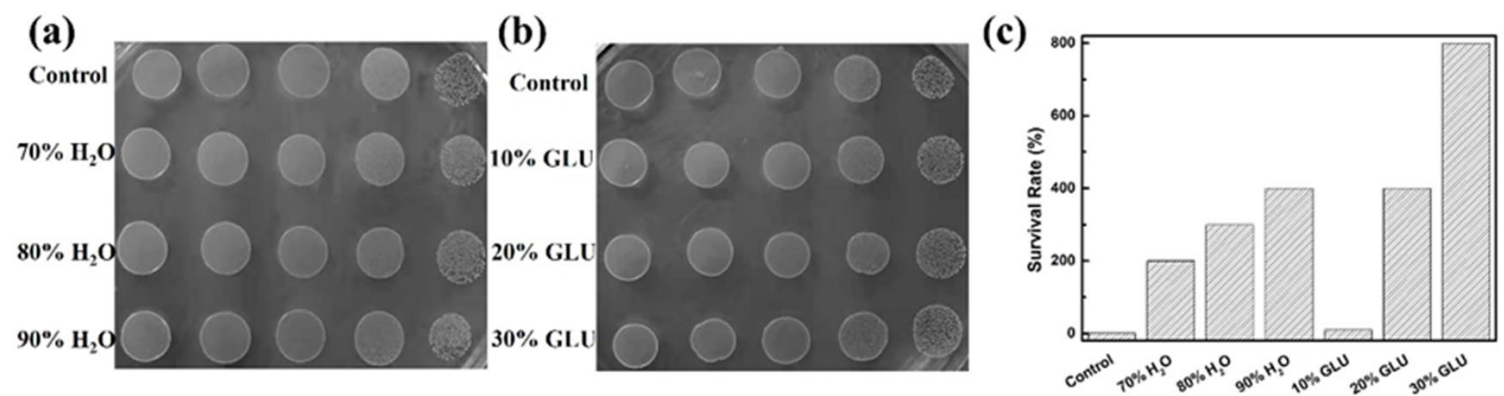

Figure 4. (a) Viable count of lactobacillus plantarum after COOH-CDs concentration $(0.1 \mathrm{~g} / \mathrm{L})$ replaced partial water and glucose (GLU); (b) Survival rate of lactobacillus plantarum competing with reference sample; (c) Survival rate of lactobacillus plantarum when $\mathrm{COOH}-\mathrm{CD}$ s partly replaced water or glucose.

\subsection{Fluorescent Selectivity and Sensitivity toward $\mathrm{Fe}^{3+}$}

CDs have been widely used as a fluorescent sensor due to their strong emission, high fluorescent sensitivity, and low cost. The rich $\mathrm{COOH}$ groups on the surface of $\mathrm{COOH}-\mathrm{CDs}$ can easily coordinate with metal ions, leading to a significant variation of fluorescent emission [36]. Therefore, the fluorescent selectivity and sensitivity of $\mathrm{COOH}-\mathrm{CDs}$ toward different kinds of metal ions were further investigated (Figure 5a). It can be clearly seen that the prepared $\mathrm{COOH}-\mathrm{CDs}$ had high selectivity toward $\mathrm{Fe}^{3+}$ than other metal ions. Furthermore, the PL intensity remarkably decreased with the increase in $\mathrm{Fe}^{3+}$ addition, indicating that $\mathrm{COOH}-\mathrm{CDs}$ had high fluorescent sensitivity toward $\mathrm{Fe}^{3+}$ and can be developed as an excellent fluorescent sensor for $\mathrm{Fe}^{3+}$ detection. To further evaluate the sensitivity of $\mathrm{COOH}-\mathrm{CDs}$ toward $\mathrm{Fe}^{3+}$, Stern-Volmer plots with quenching efficiency as the $Y$-axis and $\mathrm{Fe}^{3+}$ concentration as the $X$-axis were analyzed. As shown in Figure $5 \mathrm{c}$, the plot showed an upward trend with the increasing concentration of $\mathrm{Fe}^{3+}$ in the range of $0-6.62 \mu \mathrm{M}$. Intriguingly, the plot was an approximate straight line with a good linear relationship $\left(R^{2}=0.9923\right.$ ) under low concentration (Figure $5 \mathrm{~d}$ ), which means that the $\mathrm{COOH}-\mathrm{CDs}$ had great potential in $\mathrm{Fe}^{3+}$ fluorescent sensing detection. The correlation can be formulated with the following equation [20].

$$
1-\frac{I}{I_{0}}=K_{s v}[M]
$$

where $I$ and $I_{0}$ represent the fluorescent intensity of $\mathrm{COOH}-\mathrm{CD}$ s with and without $\mathrm{Fe}^{3+}$ respectively, $K_{s v}$ represents the quenching constant that can be calculated from the slope of Stern-Volmer plot, and $[M]$ is the concentration of $\mathrm{Fe}^{3+}$.

To further evaluate the fluorescent sensitivity of $\mathrm{COOH}-\mathrm{CD}$ s toward $\mathrm{Fe}^{3+}$, the limit of detection (LoD) was calculated by Equation (3), where $S_{d}$ stands for the intensity standard deviation of the blank samples measured 10 times, and $K_{s v}$ is the quenching constant of Stern-Volmer plots $[37,38]$. The LoD of COOH-CDs toward $\mathrm{Fe}^{3+}$ is determined to be $3.18 \mathrm{nM}$, which is lower than many related reports (Table 1). It indicates that $\mathrm{COOH}-\mathrm{CDs}$ is an excellent potential candidate for $\mathrm{Fe}^{3+}$ detection.

$$
L o D=\frac{3 S_{d}}{K_{s v}}
$$


(a)
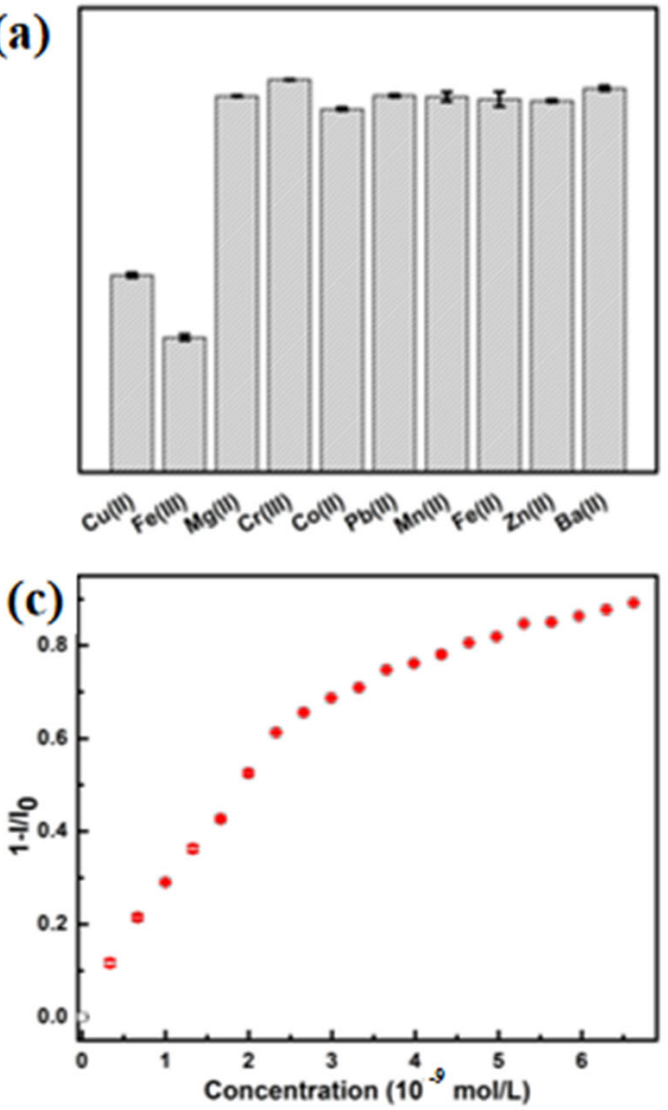

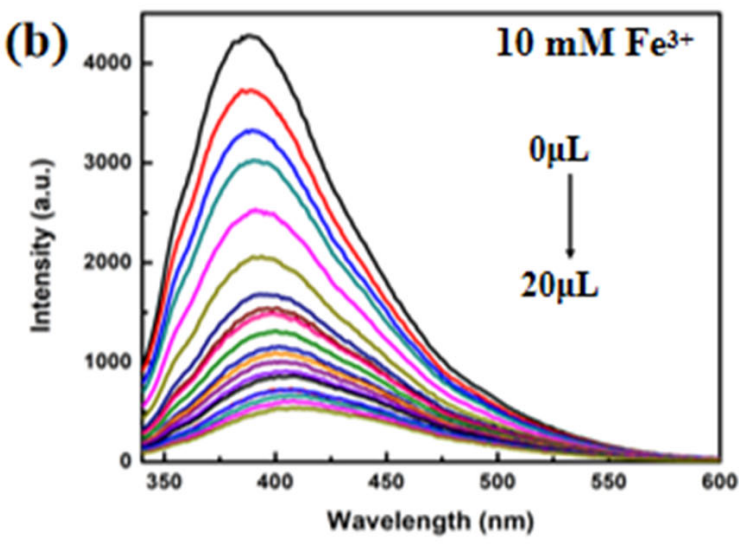

(d)

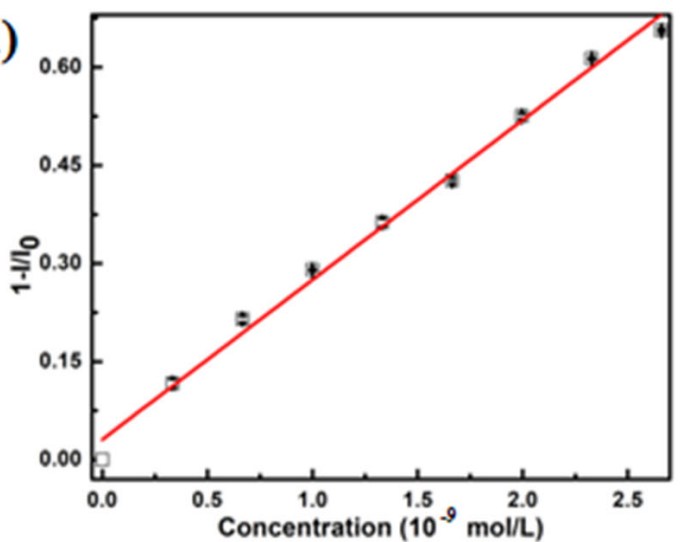

Figure 5. (a) Selectivity of COOH-CDs $(0.1 \mathrm{~g} / \mathrm{L})$ over different kinds of metal ions (10-3 M); (b) PL response of COOH-CDs with different concentrations of $\mathrm{Fe}^{3+} ;(\mathbf{c}, \mathbf{d})$ Stern-Volmer plot of $\mathrm{COOH}-\mathrm{CD}$ toward $\mathrm{Fe}^{3+}$.

Table 1. Fluorescence sensors in the literature for $\mathrm{Fe}^{3+}$ detection.

\begin{tabular}{cccc}
\hline Sensor System & Analyte & Limit of Detection (LoD) & Refs. \\
\hline $\begin{array}{c}\text { Carbon dot decorated natural } \\
\text { microcline membrane }\end{array}$ & $\mathrm{Fe}^{3+}$ & $61.6 \mu \mathrm{M}$ & {$[39]$} \\
Carbon dots & $\mathrm{Fe}^{3+}$ & $0.16 \mu \mathrm{M}$ & {$[40]$} \\
Carbon dots & $\mathrm{Fe}^{3+}$ & $0.703 \mu \mathrm{M}$ & {$[41]$} \\
Polyurethane-nitrogen-doped & $\mathrm{Fe}^{3+}$ & $10.10 \mu \mathrm{M}$ & {$[42]$} \\
carbon dot nanocomposites & $\mathrm{Fe}^{3+}$ & $87 \mathrm{nM}$ & {$[43]$} \\
B, N, S-doped carbon dots & $\mathrm{Fe}^{3+}$ & $0.21 \mu \mathrm{M}$ & {$[44]$} \\
S-doped silicon quantum dots & $\mathrm{Fe}^{3+}$ & $0.897 \mu \mathrm{M}$ & {$[45]$} \\
Eu ${ }^{3+}$-doped metal-organic & & $0.74 \mu \mathrm{M}$ & {$[46]$} \\
framework & $\mathrm{Fe}^{3+}$ & $0.1 \mu \mathrm{M}$ & {$[47]$} \\
N, B-co-doped carbon dots & $\mathrm{Fe}^{3+}$ & $0.17 \mu \mathrm{M}$ & {$[48]$} \\
N, P-doped carbon dots & $\mathrm{Fe}^{3+}$ & & \\
Biomass-based polymer & nanoparticles & &
\end{tabular}

\subsection{Theoretical Analysis for the Selectivity of COOH-CDs toward Metal Ions}

In this paper, $\mathrm{COOH}$ functionalized coronene was selected as the model to further study the interactions property between $\mathrm{COOH}-\mathrm{CD}$ and metal ions. It can be seen from the optimized geometries of $\mathrm{COOH}-\mathrm{CDs} / \mathrm{M}^{\mathrm{n}+}$ complexes in Figure 6 that metal ions were absorbed on the surface of $\mathrm{COOH}-\mathrm{CD}$ to form stable complexes (except for $\mathrm{Cr}^{3+}$ ) with different bonded properties. Obviously, $\mathrm{Fe}^{3+}(2.05 \AA), \mathrm{Fe}^{2+}(2.03 \AA), \mathrm{Cu}^{2+}(2.04 \AA)$, and $\mathrm{Co}^{2+}$ $(2.02 \AA)$ were strongly bonded on the surface of $\mathrm{COOH}-\mathrm{CDs}$, for the bond distances were shorter than those of other metal ions [49]. The results also reflected the binding energies 
(BEs) of the COOH-CDs $/ \mathrm{M}^{\mathrm{n}+}$ complexes listed in Table 2, and the order of the stability for the $\mathrm{COOH}-\mathrm{CDs} / \mathrm{M}^{\mathrm{n}+}$ complexes is $\mathrm{Fe}^{3+}>>\mathrm{Cu}^{2+}>\mathrm{Co}^{2+}>\mathrm{Zn}^{2+}>\mathrm{Fe}^{2+}>\mathrm{Mn}^{2+}>\mathrm{Mg}^{2+}>$ $\mathrm{Pb}^{2+}>\mathrm{Ba}^{2+}$. Obviously, $\mathrm{Fe}^{3+}$ had the strongest interaction property toward $\mathrm{COOH}-\mathrm{CDs}$ as the $\mathrm{BE}$ is the highest, indicating that $\mathrm{COOH}-\mathrm{CD}$ s preferred to adsorb $\mathrm{Fe}^{3+}$ rather than other metal ions.

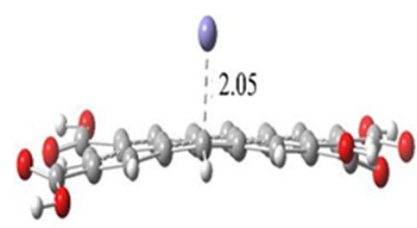

$\mathrm{COOH}-\mathrm{CDs} / \mathrm{Fe}^{3+}$

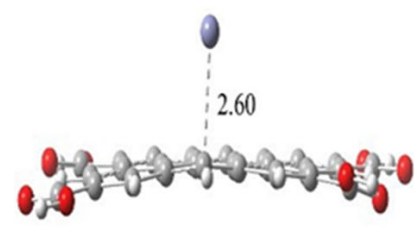

$\mathrm{COOH}-\mathrm{CDs} / \mathrm{Zn}^{2+}$

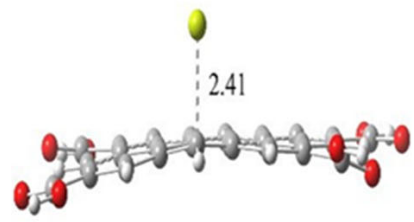

$\mathrm{COOH}-\mathrm{CDs} / \mathrm{Mg}^{2+}$

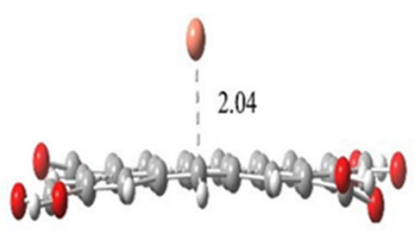

$\mathrm{COOH}-\mathrm{CDs} / \mathrm{Cu}^{2+}$



$\mathrm{COOH}-\mathrm{CDs} / \mathrm{Fe}^{2+}$



$\mathrm{COOH}-\mathrm{CDs} / \mathrm{Pb}^{2+}$



$\mathrm{COOH}-\mathrm{CDs} / \mathrm{Co}^{2+}$
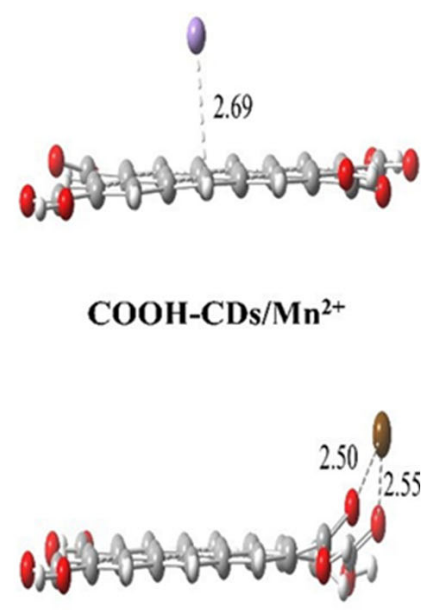

$\mathrm{COOH}-\mathrm{CDs} / \mathrm{Ba}^{2+}$

Figure 6. Optimized geometries of $\mathrm{COOH}-\mathrm{CDs} / \mathrm{M}^{\mathrm{n}+}$ complexes along with the key bond distances (in $\AA$ ).

Table 2. Calculated binding energies (BEs), HOMO-LUMO energy gap (Egs), and metal ion charge distributions for surface-adsorbed $\mathrm{COOH}-\mathrm{CDs} / \mathrm{M}^{\mathrm{n}+}$ complexes.

\begin{tabular}{cccc}
\hline $\begin{array}{c}\text { COOH-CDs/Mn+ } \\
\text { Complexes }\end{array}$ & BEs (kcal/mol) & Egs (eV) & $\begin{array}{c}\text { Charge Distributions at } \\
\mathbf{M}^{\mathbf{n}+} \text { Surface }\left(\boldsymbol{\Delta}^{\mathbf{a}}\right) \mathbf{( a . u . )}\end{array}$ \\
\hline $\mathrm{COOH}-\mathrm{CDs} / \mathrm{Fe}^{3+}$ & -593.82 & 1.87 & $0.87(-2.13)$ \\
$\mathrm{COOH}-\mathrm{CDs} / \mathrm{Cu}^{2+}$ & -291.52 & 2.11 & $0.78(-1.22)$ \\
$\mathrm{COOH}-\mathrm{CDs} / \mathrm{Co}^{2+}$ & -229.54 & 2.15 & $1.34(-0.63)$ \\
$\mathrm{COOH}-\mathrm{CDs} / \mathrm{Zn}^{2+}$ & -211.19 & 2.14 & $1.70(-0.30)$ \\
$\mathrm{COOH}-\mathrm{CDs} / \mathrm{Fe}^{2+}$ & -198.64 & 2.33 & $1.47(-0.53)$ \\
$\mathrm{COOH}-\mathrm{CDs} / \mathrm{Mn}^{2+}$ & -169.55 & 2.52 & $1.68(-0.32)$ \\
$\mathrm{COOH}-\mathrm{CDs} / \mathrm{Mg}^{2+}$ & -146.23 & 2.40 & $1.77(-0.23)$ \\
$\mathrm{COOH}-\mathrm{CDs} / \mathrm{Pb}^{2+}$ & -122.68 & 2.45 & $1.28(-0.72)$ \\
$\mathrm{COOH}-\mathrm{CDs} / \mathrm{Ba}^{2+}$ & -114.39 & 2.68 & $1.47(-0.53)$ \\
$\mathrm{COOH}-\mathrm{CDs} / \mathrm{Cr}^{3+}$ & $-{ }^{\mathrm{b}}$ & $-{ }^{\mathrm{b}}$ & $-\mathrm{b}$ \\
\hline
\end{tabular}

${ }^{\mathrm{a}}$ Calculated charges transfer from $\mathrm{COOH}-\mathrm{CD}$ to metal ions. ${ }^{\mathrm{b}}$ Convergence error.

Furthermore, frontier molecular orbital (FMO) of $\mathrm{COOH}-\mathrm{CDs} / \mathrm{M}^{\mathrm{n}+}$ complexes were also investigated to understand the effect $\mathrm{COOH}-\mathrm{CDs}$ and metal ions charge. The isosurfaces of the HOMOs and LUMOs orbitals (showed in Figure 7) and the calculated highest occupied molecular orbitals (HOMO) and lowest unoccupied molecular orbitals (LUMO) energy gaps (Egs, listed in Table 2) were further analyzed. The isosurfaces of 
the HOMOs and LUMOs orbitals were used to depict the orbital interactions between $\mathrm{COOH}-\mathrm{CDs}$ and metal ions. It was found that all the HOMOs mainly localized in the carbon plane of $\mathrm{COOH}-\mathrm{CDs}$, while LUMOs apparently transferred to metal ions. This phenomenon is especially obvious in the $\mathrm{COOH}-\mathrm{CDs} / \mathrm{Fe}^{3+}$ complex, where more than half of the LUMO transferred to $\mathrm{Fe}^{3+}$ ions to generate a stable system with high hybridization. According to the literature, lower Egs reflected the hybridization degree of metal ions with functionalized CDs [49]. Comparing with other metal ions, $\mathrm{Fe}^{3+}$ with the lowest Egs $(1.87 \mathrm{eV})$ presented perfect hybridization with $\mathrm{COOH}-\mathrm{CDs}$. Combining the geometries and FMO results, it can be concluded that $\mathrm{COOH}-\mathrm{CDs}$ preferred to absorb $\mathrm{Fe}^{3+}$ on its surface to form a stable complex rather than other metal ions, which was in good agreement with the fluorescent selectivity and sensitivity toward $\mathrm{Fe}^{3+}$.

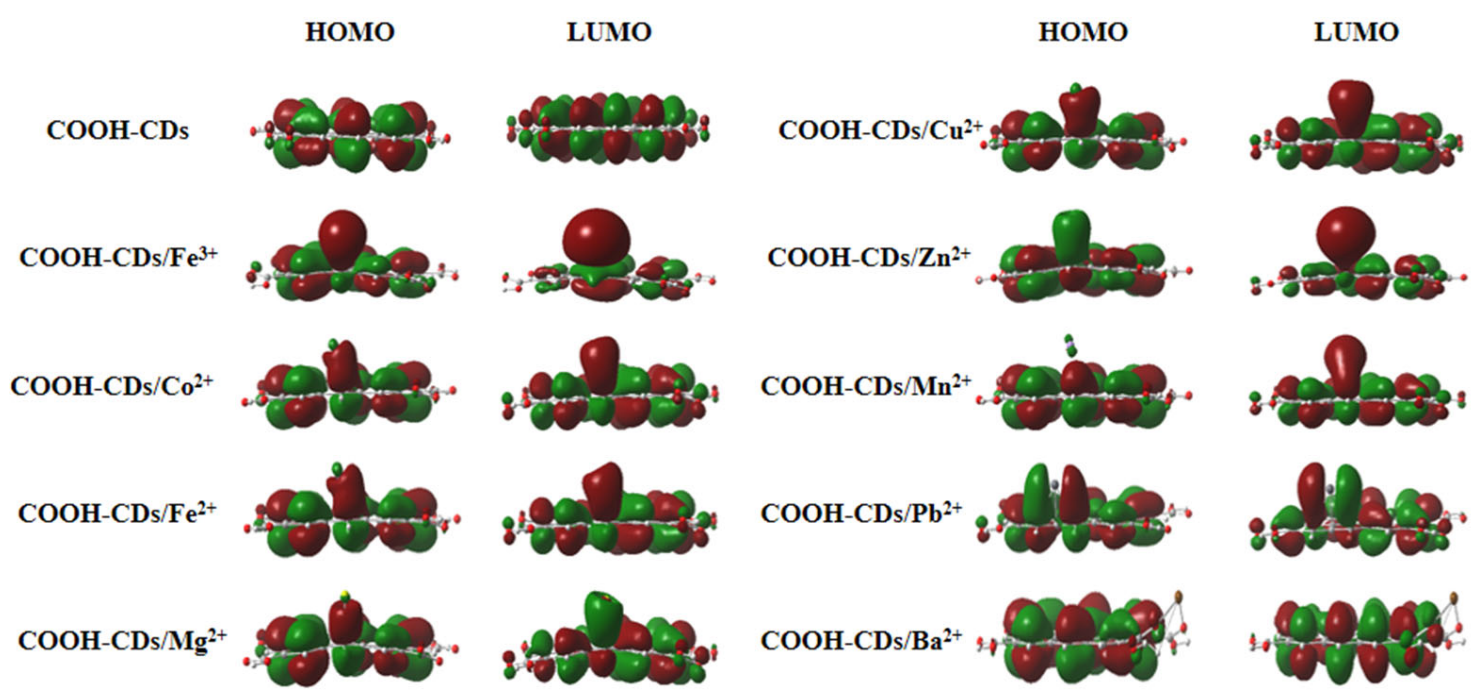

Figure 7. Isosurfaces of $\mathrm{HOMO}$ and LUMO of $\mathrm{COOH}-\mathrm{CDs} / \mathrm{Mn}+$ complexes.

\subsection{Fluorescent Sensing Performance of LF}

As a natural functional protein, the binding capacity to $\mathrm{Fe}^{3+}$ endows lactoferrin (LF) antibacterial ability, ferric balance adjusting, immunity enhancement, and other functions [50]. As the binding reaction between $\mathrm{LF}$ and $\mathrm{Fe}^{3+}$ is reversible, fluorescent compound with strong binding capacity to $\mathrm{Fe}^{3+}$ can capture $\mathrm{Fe}^{3+}$ from lactoferrin and lead to the change of PL emission. Therefore, the prepared $\mathrm{COOH}-\mathrm{CDs}$ with highly fluorescent selectivity and sensitivity toward $\mathrm{Fe}^{3+}$ were selected as the fluorescent sensor for LF detection. PL emission changes of $\mathrm{COOH}-\mathrm{CDs}$ as the lactoferrin concentration increased were measured. As shown in Figure 8a, the PL intensity of COOH-CDs decreased with the increasing of lactoferrin concentration. The Stern-Volmer plot presented a straight trend with a good linear relationship $\left(R^{2}=0.9815\right)$ when the concentration of LF increased from 0 to $6.62 \mu \mathrm{g} / \mathrm{mL}$. According to the Stern-Volmer curve for COOH-CDs toward LF, the LoD value was calculated to be $0.776 \mu \mathrm{g} / \mathrm{mL}$, which is lower than those of other related methods (Table 3). It indicates that the prepared $\mathrm{COOH}-\mathrm{CDs}$ have potential as a fluorescent sensor for LF detection. 

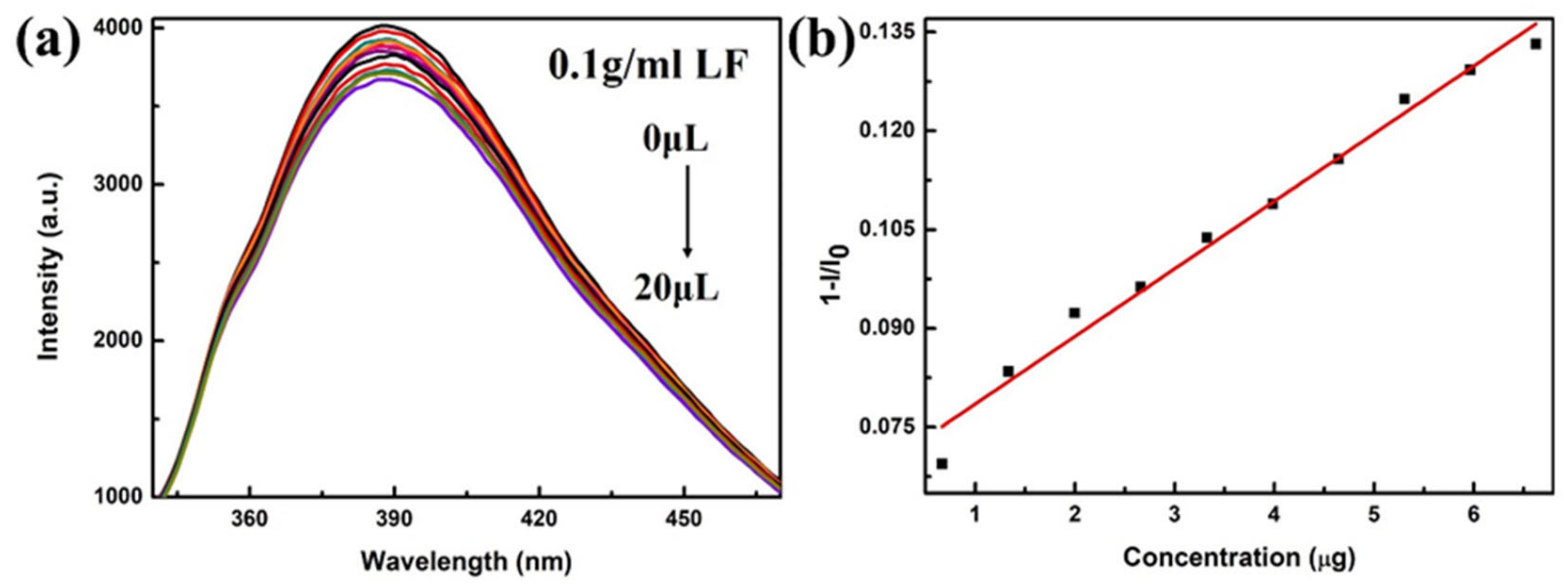

Figure 8. (a) PL response of COOH-CDs with different concentrations of lactoferrin (LF); (b) Stern-Volmer plot of COOHCDs toward LF.

Table 3. Different detection methods in the literature for LF detection.

\begin{tabular}{cccc}
\hline Detect Method & Analyte & Limit of Detection (LoD) & Refs. \\
\hline Thin-Layer Chromatography & LF & $3.5 \mu \mathrm{g} / \mathrm{mL}$ & {$[10]$} \\
Colorimetric & LF & $110 \mu \mathrm{g} / \mathrm{mL}$ & {$[9]$} \\
HPLC-UV & LF & $35.4 \mu \mathrm{g} / \mathrm{mL}$ & {$[51]$} \\
HPLC & LF & $0.57 \mathrm{mg} / \mathrm{L}$ & {$[11]$} \\
Sandwich Immunoassay & LF & $3.23 \mathrm{ng} / \mathrm{mL}$ & {$[52]$} \\
Ultrahigh-Performance Liquid & & $3.8 \mathrm{mg} / \mathrm{kg}$ & {$[53]$} \\
Chromatography-Tandem Mass & LF & & \\
Spectrometry & & $1 \mathrm{mg} / 100 \mathrm{~g}$ & \\
Ultrahigh-Performance Liquid & LF & & \\
Chromatography-Tandem & & &
\end{tabular}

\section{Conclusions}

In summary, we developed an efficient method for $\mathrm{Fe}^{3+}$ and LF detection using $\mathrm{COOH}-\mathrm{CDs}$ as the fluorescent sensor. $\mathrm{COOH}-\mathrm{CDs}$ exhibited high selectivity and sensitivity toward $\mathrm{Fe}^{3+}$ with an LoD of $3.18 \mathrm{nM}$. The results of theoretical calculations indicated that the excellent performance can be attributed to the binding energy between $\mathrm{COOH}-\mathrm{CDs}$ and $\mathrm{Fe}^{3+}(-593.82 \mathrm{kcal} / \mathrm{mol})$ being much higher than other ions, leading to a sensitive fluorescence response. Meanwhile, $\mathrm{COOH}-\mathrm{CDs}$ showed no obvious effect on lactobacillus plantarum growth, which means that $\mathrm{COOH}-\mathrm{CDs}$ have good biocompatibility. Due to the nontoxicity and excellent detection performance for $\mathrm{Fe}^{3+}, \mathrm{COOH}-\mathrm{CDs}$ were employed as a fluorescent sensor toward LF and showed high sensitivity with an LoD of $0.776 \mu \mathrm{g} / \mathrm{mL}$. This work can provide a new avenue to design a fluorescent sensor with high performance for LF in practical applications.

Author Contributions: Data curation, T.W. and H.W.; Formal analysis, X.W., T.W., K.T. and Y.G.; Funding acquisition, Y.L.; Investigation, X.W., Y.Z., Y.G. and H.W.; Methodology, X.W., Y.Z., T.W., X.Z. and Y.G.; Project administration, Y.L. and K.T.; Software, Y.Z., T.W. and X.Z.; Supervision, Y.L. and H.W.; Validation, X.W., Y.Z. and K.T.; Visualization, Y.G.; Writing-original draft, X.W.; Writingreview \& editing, Y.L., X.Z., K.T. and H.W. All authors have read and agreed to the published version of the manuscript.

Funding: This work was financially supported by the Major Science and Technology Innovation Projects of Shandong Province (No. 2020CXGC010604), the National Training Program of Innovation and Entrepreneurship for Undergraduates (No. 202110431003), the Development Plan of Youth Innovation Team in Colleges and Universities of Shandong Province (No. 2020KJE005), and the Foundation of State Key Laboratory of Biobased Material and Green Papermaking (No. ZR20190105). 
Conflicts of Interest: The authors declare no conflict of interest.

\section{References}

1. Wang, B.; Timilsena, Y.P.; Blanch, E.; Adhikari, B. Lactoferrin: Structure, function, denaturation and digestion. Crit. Rev. Food Sci. Nutr. 2019, 59, 580-596. [CrossRef] [PubMed]

2. $\quad$ Pang, J.J.; Xiao, Q.Q.; Yan, H.; Cao, Y.Q.; Miao, J.J.; Wang, S.M.; Li, X.F.; Li, H.; Cheng, Z.Z. Bovine Lactoferrin Quantification in Dairy Products by a Simple Immunoaffinity Magnetic Purification Method Coupled with High-Performance Liquid Chromatography with Fluorescence Detection. J. Agric. Food. Chem. 2020, 68, 892-898. [CrossRef]

3. Habing, G.; Harris, K.; Schuenemann, G.M.; Pineiro, J.M.; Lakritz, J.; Clavijo, X.A. Lactoferrin reduces mortality in preweaned calves with diarrhea. J. Dairy Sci. 2017, 100, 3940-3948. [CrossRef]

4. Chang, R.; Ng, T.B.; Sun, W.Z. Lactoferrin as potential preventative and adjunct treatment for COVID-19. Int. J. Antimicrob. Agents 2020, 56, 106118. [CrossRef] [PubMed]

5. Habib, H.M.; Ibrahim, S.; Zaim, A.; Ibrahim, W.H. The role of iron in the pathogenesis of COVID-19 and possible treatment with lactoferrin and other iron chelators. Biomed. Pharm. Ther. 2021, 136, 111228. [CrossRef] [PubMed]

6. Campione, E.; Lanna, C.; Cosio, T.; Rosa, L.; Conte, M.P.; Iacovelli, F.; Romeo, A.; Falconi, M.; Del Vecchio, C.; Franchin, E.; et al. Lactoferrin Against SARS-CoV-2: In Vitro and In Silico Evidences. Front. Pharmacol. 2021, 12, 666600. [CrossRef] [PubMed]

7. Indyk, H.E.; McGrail, I.J.; Watene, G.A.; Filonzi, E.L. Optical biosensor analysis of the heat denaturation of bovine lactoferrin. Food Chem. 2007, 101, 838-844. [CrossRef]

8. Ke, X.; Chen, Q.; Pan, X.D.; Zhang, J.S.; Mo, W.M.; Ren, Y.P. Quantification of lactoferrin in breast milk by ultra-high performance liquid chromatography-tandem mass spectrometry with isotopic dilution. RSC Adv. 2016, 6, 12280-12285. [CrossRef]

9. Kudo, H.; Maejima, K.; Hiruta, Y.; Citterio, D. Microfluidic Paper-Based Analytical Devices for Colorimetric Detection of Lactoferrin. Slas Technol. 2020, 25, 47-57. [CrossRef] [PubMed]

10. El-Hawiet, A. A Simple, Sensitive, and Label-Free Platform for the Quantification of Lactoferrin in Camel and Goat Milk Based on Thin-Layer Chromatography. Chromatographia 2017, 80, 1797-1804. [CrossRef]

11. Chen, M.X.; Wen, F.; Zhang, Y.D.; Li, P.; Zheng, N.; Wang, J.Q. Determination of native lactoferrin in milk by HPLC on HiTrap Heparin HP column. Food Anal. Method. 2019, 12, 2518-2526. [CrossRef]

12. Baker, E.N.; Baker, H.M. A structural framework for understanding the multifunctional character of lactoferrin. Biochimie 2009, 91, 3-10. [CrossRef] [PubMed]

13. Kay, C.W.M.; El Mkami, H.; Cammack, R.; Evans, R.W. Pulsed ELDOR determination of the intramolecular distance between the metal binding sites in dicupric human serum transferrin and lactoferrin. J. Am. Chem. Soc. 2007, 129, 4868. [CrossRef]

14. Gibbons, J.A.; Kanwar, J.R.; Kanwar, R.K. Iron-free and iron-saturated bovine lactoferrin inhibit survivin expression and differentially modulate apoptosis in breast cancer. BMC Cancer 2015, 15, 425. [CrossRef] [PubMed]

15. Lee, S.H.; Pyo, C.W.; Hahm, D.H.; Kim, J.; Choi, S.Y. Iron-saturated lactoferrin stimulates cell cycle progression through PI3K/Akt pathway. Mol. Cells 2009, 28, 37-42. [CrossRef] [PubMed]

16. Jenssen, H.; Hancock, R.E.W. Antimicrobial properties of lactoferrin. Biochimie 2009, 91, 19-29. [CrossRef]

17. Sui, B.W.; Zhang, Y.P.; Huang, L.; Chen, Y.X.; Li, D.W.; Li, Y.F.; Yang, B. Fluorescent Nanofibrillar Hydrogels of Carbon Dots and Cellulose Nanocrystals and Their Biocompatibility. ACS Sustain. Chem. Eng. 2020, 8, 18492-18499. [CrossRef]

18. Yang, Y.S.; Gu, B.L.; Liu, Z.D.; Chen, D.; Zhao, Y.; Guo, Q.L.; Wang, G. Hydrothermal synthesis of N, P co-doped graphene quantum dots for high-performance $\mathrm{Fe}^{3+}$ detection and bioimaging. J. Nanopart. Res. 2021, 23, 40. [CrossRef]

19. Ge, L.; Yu, H.L.; Ren, H.T.; Shi, B.; Guo, Q.; Gao, W.S.; Li, Z.Q.; Li, J.G. Photoluminescence of carbon dots and their applications in Hela cell imaging and $\mathrm{Fe}^{3+}$ ion detection. J. Mater. Sci. 2017, 52, 9979-9989. [CrossRef]

20. Liang, Y.; Xu, L.X.; Tang, K.; Guan, Y.T.; Wang, T.; Wang, H.; Yu, W.W. Nitrogen-doped carbon dots used as an "on-off-on" fluorescent sensor for $\mathrm{Fe}^{3+}$ and glutathione detection. Dye. Pigment. 2020, 178, 108358. [CrossRef]

21. Chu, X.H.; Wu, F.; Sun, B.H.; Zhang, M.; Song, S.J.; Zhang, P.; Wang, Y.L.; Zhang, Q.C.; Zhou, N.L.; Shen, J. Genipin cross-linked carbon dots for antimicrobial, bioimaging and bacterial discrimination. Colloid. Surf. B 2020, 190, 110930. [CrossRef]

22. Abdel-Kader, N.S.; Abdel-Latif, S.A.; El-Ansary, A.L.; Sayed, A.G. Spectroscopic studies, density functional theory calculations, non-linear optical properties, biological activity of 1-hydroxy-4-((4-(N-(pyrimidin-2-yl)sulfamoyl)phenyl)diazenyl)-2-naphthoic acid and its chelates with Nickel (II), Copper (II), Zinc (II) and Palladium (II) metal ions. J. Mol. Struct. 2021, $1223,129203$.

23. Rao, J.S.; Sastry, G.N. Structural and Energetic Preferences of pi, sigma, and Bidentate Cation Binding $\left(\mathrm{Li}^{+}, \mathrm{Na}^{+}\right.$, and $\left.\mathrm{Mg}^{2+}\right)$ to Aromatic Amines (Ph- $\left.\left(\mathrm{CH}_{2}\right)(\mathrm{n})-\mathrm{NH}_{2}, \mathrm{n}=2-5\right)$ : A Theoretical Study. J. Phys. Chem. A 2009, 113, 5446-5454. [CrossRef]

24. Yadegari, A.; Khezri, J.; Esfandiari, S.; Mandavi, H.; Karkhane, A.A.; Rahighi, R.; Heidarimoghadam, R.; Tayebi, L.; Hashemi, E.; Farmany, A. Bottom-up synthesis of nitrogen and oxygen co-decorated carbon quantum dots with enhanced DNA plasmid expression. Colloid. Surf. B 2019, 184, 110543. [CrossRef] [PubMed]

25. Tahir, N.; Madni, A.; Kashif, P.M.; Rehman, M.; Raza, A.; Khan, M.I.; Rahim, M.A.; Jabar, A. Formulation and compatibility assessment of PLGA/lecithin based lipid-polymer hybrid nanoparticles containing doxorubicin. Acta Pol. Pharm. 2017, 74, 1563-1572.

26. Kime, G.; Zhou, K.G.; Hardman, S.J.O.; Nair, R.R.; Novoselov, K.S.; Andreeva, D.V.; Binks, D.J. pH Dependence of Ultrafast Charge Dynamics in Graphene Oxide Dispersions. J. Phycs. Chem. C 2019, 123, 10677-10681. [CrossRef] 
27. He, S.J.; Turnbull, M.J.; Nie, Y.T.; Sun, X.H.; Ding, Z.F. Band structures of blue luminescent nitrogen-doped graphene quantum dots by synchrotron-based XPS. Surf. Sci. 2018, 676, 51-55. [CrossRef]

28. Bogireddy, N.K.R.; Silva, R.C.; Valenzuela, M.A.; Agarwal, V. 4-nitrophenol optical sensing with N doped oxidized carbon dots. J. Hazard. Mater. 2020, 386, 121643. [CrossRef] [PubMed]

29. Liu, S.; Xin, Z.J.; Lei, Y.J.; Yang, Y.; Yan, X.Y.; Lu, Y.B.; Li, C.B.; Wang, H.Y. Thin Copper-Based Film for Efficient Electrochemical Hydrogen Production from Neutral Aqueous Solutions. ACS Sustain. Chem. Eng. 2017, 5, 7496-7501. [CrossRef]

30. Lee, D.S.; Park, S.J. Water-mediated modulation of $\mathrm{TiO}_{2}$ decorated with graphene for photocatalytic degradation of trichloroethylene. Curr. Appl. Phys. 2015, 15, 144-148. [CrossRef]

31. Mohai, M.; Laszlo, K.; Bertoti, I. Reduction and covalent modification of graphene-oxide by nitrogen in glow discharge plasma. Surf. Interface Anal. 2018, 50, 1207-1212. [CrossRef]

32. Zhang, X.; Zhang, J.; Yan, Z.W.; Zhou, X.Y.; Zhang, F.J. Purification of PTCDA by Vacuum Sublimation and Spectral Test and Analysis. Spectrosc. Spect. Anal. 2015, 35, 885-888.

33. Wang, J.L.; Wang, Y.L.; Zheng, J.X.; Yu, S.P.; Yang, Y.Z.; Liu, X.G. Mechanism, Tuning and Application of Excitation-Dependent Fluorescence Property in Carbon Dots. Prog. Chem. 2018, 30, 1186-1201.

34. Ehtesabi, H.; Hallaji, Z.; Nobar, S.N.; Bagheri, Z. Carbon dots with pH-responsive fluorescence: A review on synthesis and cell biological applications. Microchimi. Acta 2020, 187, 150. [CrossRef]

35. Hu, Y.P.; Gao, Z.J. Highly Photoluminescent Carbon Dots Derived from Discarded Chewing Gum: Toward Multiple Sensing of $\mathrm{pH}$, Ferric Ion, and Adenosine Triphosphate. Chem. Sel. 2019, 4, 12807-12814. [CrossRef]

36. Liu, H.; Zhang, Y.; Liu, J.H.; Hou, P.; Zhou, J.; Huang, C.Z. Preparation of nitrogen-doped carbon dots with high quantum yield from Bombyx mori silk for Fe(III) ions detection. RSC Adv. 2017, 7, 50584-50590. [CrossRef]

37. Baig, M.M.F.; Chen, Y.C. Bright carbon dots as fluorescence sensing agents for bacteria and curcumin. J. Colloid Interface Sci. 2017, 501, 341-349. [CrossRef]

38. Liang, Y. A silicon-cored tetraphenyl benzene derivative with aggregation-induced emission enhancement as a fluorescent probe for nitroaromatic compounds detection. Spectrochim. Acta A Mol. Biomol. Spectrosc. 2019, 216, 395-403. [CrossRef] [PubMed]

39. Bardhan, S.; Roy, S.; Chanda, D.K.; Mondal, D.; Das, S.; Das, S. Flexible and reusable carbon dot decorated natural microcline membrane: A futuristic probe for multiple heavy metal induced carcinogen detection. Microchimi. Acta 2021, 188, 134. [CrossRef] [PubMed]

40. An, Q.X.; Lin, Q.L.; Huang, X.H.; Zhou, R.J.; Guo, X.; Xu, W.Z.; Wang, S.Y.; Xu, D.; Chang, H.T. Electrochemical synthesis of carbon dots with a Stokes shift of $309 \mathrm{~nm}$ for sensing of $\mathrm{Fe}^{3+}$ and ascorbic acid. Dye. Pigment. 2021, 185, 108878. [CrossRef]

41. Li, Y.Y.; Chen, J.J.; Wang, Y.P.; Li, H.J.; Yin, J.H.; Li, M.Y.; Wang, L.; Sun, H.J.; Chen, L.X. Large-scale direct pyrolysis synthesis of excitation-independent carbon dots and analysis of ferric (III) ion sensing mechanism. Appl. Surf. Sci. 2021, 538, 148151. [CrossRef]

42. Nanbedeh, S.; Faghihi, K. Synthesis and Characterization of New Mesoporous Polyurethane-Nitrogen Doped Carbon Dot Nanocomposites: Ultrafast, Highly Selective and Sensitive Turn-off Fluorescent Sensors for Fe ${ }^{3+}$ Ions. J. Fluoresc. 2021, 31, 517-539. [CrossRef] [PubMed]

43. Song, S.M.; Hu, J.H.; Li, M.L.; Gong, X.J.; Dong, C.; Shuang, S.M. Fe ${ }^{3+}$ and intracellular pH determination based on orange fluorescence carbon dots co-doped with boron, nitrogen and sulfur. Mat. Sci. Eng. C-Mater. 2021, 118, 111478. [CrossRef] [PubMed]

44. Zhang, X.S.; Li, C.H.; Zhao, S.L.; Pang, H.Y.; Han, Y.; Luo, X.L.; Tang, W.Z.; Li, Z.H. S doped silicon quantum dots with high quantum yield as a fluorescent sensor for determination of $\mathrm{Fe}^{3+}$ in water. Opt. Mater. 2020, 110, 110461. [CrossRef]

45. Guo, X.P.; Pan, Q.W.; Song, X.Q.; Guo, Q.Y.; Zhou, S.X.; Qiu, J.R.; Dong, G.P. Embedding carbon dots in Eu ${ }^{3+}$-doped metal-organic framework for label-free ratiometric fluorescence detection of $\mathrm{Fe}^{3+}$ ions. J. Am. Ceram. Soc. 2021, 104, 886-895. [CrossRef]

46. Zhang, L.X.; Zhang, Z.S.; Gao, Z.W.; Xie, Y.; Shu, S.; Ke, Y.E.; Wang, Y.; Deng, B.; Yu, R.J.; Geng, H.L. Facile synthesis of N,B-co-doped carbon dots with the gram-scale yield for detection of iron (III) and E. coli. Nanotechnology 2020, 31, 10. [CrossRef] [PubMed]

47. Dong, G.H.; Lang, K.; Ouyang, H.; Zhang, W.Z.; Bai, L.M.; Chen, S.J.; Zhang, Z.F.; Gao, Y.Y.; Mu, Z.H.; Zhao, X.D. Facile synthesis of N, P-doped carbon dots from maize starch via a solvothermal approach for the highly sensitive detection of $\mathrm{Fe}^{3+}$. RSC Adv. 2020, 10, 33483-33489. [CrossRef]

48. Han, S.Y.; Ni, J.X.; Han, Y.Q.; Ge, M.; Zhang, C.L.; Jiang, G.Q.; Peng, Z.B.; Cao, J.; Li, S.J. Biomass-Based Polymer Nanoparticles With Aggregation-Induced Fluorescence Emission for Cell Imaging and Detection of Fe ${ }^{3+}$ Ions. Front. Chem. 2020, 8, 563. [CrossRef]

49. Murugan, N.; Prakash, M.; Jayakumar, M.; Sundaramurthy, A.; Sundramoorthy, A.K. Green synthesis of fluorescent carbon quantum dots from Eleusine coracana and their application as a fluorescence 'turn-off ' sensor probe for selective detection of $\mathrm{Cu}^{2+}$. Appl. Surf. Sci. 2019, 476, 468-480. [CrossRef]

50. Baker, H.M.; Baker, E.N. A structural perspective on lactoferrin function. Biochem. Cell Biol. 2012, 90, 320-328. [CrossRef]

51. Tsakali, E.; Petrotos, K.; Chatzilazarou, A.; Stamatopoulos, K.; D’Alessandro, A.G.; Goulas, P.; Massouras, T.; Van Impe, J.F.M. Short communication: Determination of lactoferrin in Feta cheese whey with reversed-phase high-performance liquid chromatography. J. Dairy Sci. 2014, 97, 4832-4837. [CrossRef] 
52. Liu, L.Q.; Kong, D.Z.; Xing, C.R.; Zhang, X.; Kuang, H.; Xu, C.L. Sandwich immunoassay for lactoferrin detection in milk powder. Anal. Methods 2014, 6, 4742-4745. [CrossRef]

53. Li, X.; Li, Z.M.; Xu, E.M.; Chen, L.; Feng, H.; Chen, L.; Deng, L.G.; Guo, D.L. Determination of Lactoferrin in Camel Milk by Ultrahigh-Performance Liquid Chromatography-Tandem Mass Spectrometry Using an Isotope-Labeled Winged Peptide as Internal Standard. Molecules 2019, 24, 4199. [CrossRef] [PubMed] 